\title{
Brazilian women living in Portugal: work and quality of life
}

\section{Mulheres brasileiras vivendo em Portugal: trabalho e qualidade de vida}

\author{
Eliany Nazaré Oliveira ${ }^{a}$ \\ (iD) http://orcid.org/0000-0002-6408-7243 \\ E-mail: elianyyळhotmail.com \\ Manuelle Maria Marques Matias \\ (D) https://orcid.org/0000-0001-6474-8139 \\ E-mail: manumatias29ळgmail.com \\ Tamires Alexandre Félix ${ }^{c}$ \\ (D) https://orcid.org/0000-0001-9297-7764 \\ E-mail: myrisinhaळhotmail.com \\ Maria Michele Bispo Cavalcante \\ (D) https://orcid.org/0000-0003-2644-5326 \\ E-mail: michellebispocœyahoo.com.br

\section{Roberlândia Evangelista Lopes ${ }^{d}$} \\ (D) https://orcid.org/0000-0002-6810-7416 \\ E-mail: roberlandialopesळhotmail.com

\section{Félix Neto ${ }^{e}$} \\ (iD) http://orcid.org/0000-0003-0112-880X \\ E-mail: fnetoळfpce.up.pt \\ anniversidade Estadual Vale do Acaraú. Sobral, CE, Brasil. \\ bUniversidade do Estado do Rio de Janeiro. Rio de Janeiro, RJ, \\ Brasil. \\ 'Universidade Federal do Ceará. Sobral, CE, Brasil. \\ ${ }^{d}$ Centro Universitário Uninta. Sobral, CE, Brasil. \\ eUniversidade do Porto. Porto, Portugal.
}

\section{Abstract}

This article is organized around the axes migratory process, work, and quality of life. Two objectives were outlined: characterizing the sociodemographic aspects of Brazilian immigrant women in Portugal; and analyzing their situation and characteristics of work and quality of life. The study started from two working hypotheses: the first on the relation between unemployment and low quality of life; and the second on the relation between high workload and low quality of life of immigrant women. Cross-sectional study conducted from July to September 2016, in Portugal, with 682 Brazilian immigrant women over 18 years of age who lived in the country for more than 3 months. The instruments used were a socio-demographic questionnaire and the questionnaire 'Medical Outcomes Study 36-Item Short-Form Health Survey' (SF-36). The results showed a predominance of women in the age group from 18 to 38 years; married or living in a marriage-like relationship; with formal education mostly at the graduate level; with child(ren); and living in a family unit. The first study hypothesis was confirmed and the second study hypothesis was refuted.

Keywords: Emigration and Immigration; Women; Quality of Life; Labor Market.

\section{Correspondence}




\section{Resumo}

Este artigo se organiza em torno dos eixos processo migratório, trabalho e qualidade de vida. Delinearam-se dois objetivos: caracterizar os aspectos sociodemográficos de imigrantes brasileiras em Portugal e analisar sua situação e suas características de trabalho e qualidade de vida. O trabalho partiu de duas hipóteses de trabalho: a primeira sobre a relação entre desemprego e baixa qualidade de vida e a segunda sobre a relação entre carga horária elevada e baixa qualidade de vida de mulheres imigrantes. Este estudo, transversal, foi conduzido de julho a setembro de 2016, em Portugal, com 682 imigrantes brasileiras maiores de 18 anos que viviam no país há mais de três meses. Os instrumentos utilizados foram um questionário sociodemográfico e o questionário Medical Outcomes Study 36-item short-form health survey (SF-36). Os resultados evidenciaram predominância de mulheres na faixa etária de 18 a 38 anos, casadas ou em união de fato, com escolaridade em maior proporção no nível de pós-graduação, com filho(s) e vivendo em uma composição familiar. A primeira hipótese de estudo foi confirmada e a segunda foi refutada. Palavras-chave: Emigração e Imigração; Mulheres; Qualidade de Vida; Mercado de Trabalho.

\section{Introduction}

Migration is a common phenomenon that has sparked and demanded new reflections in the global context. According to estimates of the International Organization for Migration (IOM), there are about 200 million migrants around the world today. Not infrequently, these migrants are faced with various problems in their everyday life, ranging from difficulties in entering the labor market in the countries of residence to limitations imposed on the remittance of funds to their families in the countries of origin. The international economic and financial crisis added perverse elements to this already very hard reality. Growing feelings of intolerance, discrimination, and prejudice made the contingents of immigrants particularly vulnerable in some societies (Prado; Coelho, 2015).

In this context, Colombo (2015) notes a high degree of vulnerability of migrant workers and the possibility of them becoming victims of slave labor, since there is always a risk of abuse by the employer.

Thus, there is evidence of the importance of integration into the labor market and access to good quality jobs for the psychological well-being of immigrants, as well as the existence of family ties in the country of residence, long-term intention of residing in this country, and high physical health (Teixeira; Dias, 2016).

In the case of immigrant women workers, there is also the presence of other markers of inequality, such as race, nationality, class, or religion. It is known that many of these immigrants are unable to regularize their documents upon arriving at the destination country, thus becoming a very vulnerable group, since many employers take advantage of this situation to not obey the laws regarding payment, service hours, holidays, leaves, and other labor rights. Consequently, this situation causes these women to experience precarious and marginal employment, pervaded by exclusion mechanisms and gender and ethnicracial segregation (Silva, 2013).

By studying the immigration process of Brazilian women to Portugal, Silva (2013) concluded that the categories of work, work precariousness, social segregation, and marginalization are keywords 
to understand this phenomenon. Despite the fact that work appears as one of the motivators for the migration process and main structuring point of the private and social life of these women, it must be considered that the situation of work precariousness contributes to a fragile social insertion, marked by segregation, exploitation, and stigmatization.

These questions directly affect the mental health of migrants and, consequently, their quality of life. It is necessary to consider the difficulties and disruptions arising from the described migration process regarding the questions that present themselves in acculturation (such as illegality, lack of knowledge of the language spoken in the host country, work, housing, and habits), as well as those concerning the type of migration, transit and reception, the immigration and integration policies between countries, and the legal status, in the case of irregular immigrants (Franken; Coutinho; Ramos, 2009).

We adopted the concept of quality of life defended by Minayo, Hartz and Buss (200o), which has three reference forums: (1) the historic, according to which, at a given time, the economic, social, and technological development of a specific society has a quality of life parameter different from the same society in another historic stage; (2) the cultural, for which values and needs are built and tiered differently by peoples, revealing their traditions; and (3) the stratifications or social classes.

Some authors relate the theme of quality of life to non-material values (e.g., solidarity, love, freedom, social integration, personal fulfillment, and happiness), while others associate it to material elements (e.g., food, access to clean water, housing, work, education, health, and leisure). However, there is consensus that unemployment, social exclusion, and violence constitute the antithesis of quality of life (Franken; Coutinho; Ramos, 2009).

In short, quality of life is taken as a composition of objective and subjective factors, so that the experiences lived by people in their cultural medium shall affect significantly the social, emotional, and cognitive states (Barreto; Coutinho; Ribeiro, 2009).

This article aims to study the three axes: migratory process, work, and quality of life.
Two objectives were outlined: (1) to characterize the sociodemographic aspects of Brazilian immigrant women in Portugal; and (2) to analyze the situation and characteristics of work and quality of life, taking as parameter the questionnaire Medical Outcomes Study 36-item short-form health survey (SF-36).

In this scenario, two possibilities arise:

- hypothesis 1: the Brazilian immigrant women who live without jobs in Portugal are expected to present low quality of life, based on the questionnaire SF-36;

- hypothesis 2: the Brazilian immigrant women living in Portugal and who work more than 40 hours a week are expected to present low quality of life, taking as parameter the SF-36.

\section{Method}

This is a cross-sectional study conducted from July to September 2016, in Portugal, with 682 Brazilian immigrant women over 18 years of age who lived in the country for more than 3 months. The sample size was determined by the formula to calculate infinite populations (População..., 2018). In this perspective, based on the population of 53,357 Brazilian women residing in Portugal, the minimum number of them would be 600 , considering the confidence interval (CI) of 95\%, significance level of $5 \%$, and relative sampling error of $8 \%$ (absolute sample error $=4 \%$ ). Thus, the final sample consisted of 682 participants.

The inclusion criteria were: (1) women, (2) Brazilian, (3) living in Portugal for more than three months, and (4) being older than 18 years.

The research project was presented to the Consulate General of Brazil in Porto, Lisbon, and Faro, to the Embassy of Brazil in Lisbon, and to the Mais Brasil Association in Porto. These bodies significantly supported the identification of and approach to Brazilian women living in Portugal.

Data collection occurred from July to September 2016, and two modalities were established: (1) online, through the platform LimeSurvey; and (2) in person, at the Consulate General of Brazil in Porto and in Lisbon and at the Mais Brasil Association, in Porto. 
To expand the online approach, a group was created in the social network Facebook, called Brasileiras que vivem em Portugal [Brazilian women living in Portugal]. The link to participate in the study was made available on the official pages of the Mais Brasil Association, Consulate General of Brazil in Faro, and Embassy of Brazil in Portugal, and also on the group Brasileiras que vivem em Portugal. In the in person approach, the research was presented concerning its objectives, method used, and social importance. In addition, voluntary participation to fill the sociodemographic questionnaire was asked.

In both approaches, online and in person, the participants declared their consent by signing the informed consent form.

Two instruments were used: (1) a sociodemographic questionnaire with items concerning age, marital status, education level, presence and number of children, labor market situation, time living in the country, and person(s) who they lived with; and (2) the SF-36, a generic instrument to assess quality of life made up of 36 items organized in 8 scales or components functional capacity (10 items), physical aspects (4 items), pain (2 items), general health condition (5 items), vitality (4 items), social aspects ( 2 items), emotional aspects ( 3 items), mental health ( 5 items), and one additional question to compare the current health conditions with those from the previous year.

The data were compiled in the LimeSurvey platform and processing was performed through the computer program SPSS, version 24.o. The analysis was based on descriptive statistics and the parametric test analysis of variance (Anova). The Cronbach's alpha test was adopted to assess the internal consistency of the questionnaire SF-36 (De Vellis, 1991; Marôco, 2011).

This study was carried out in the context of a broader research, named Estado de saúde e qualidade de vida de imigrantes brasileiras em Portugal [Health condition and quality of life of Brazilian immigrant women in Portugal], approved by the Research Ethics Committee of the State University Vale do Acaraú (UVA), under the opinion no. 1,692,063, in accordance with the resolution of the National Health Council (CNS) no. 466/2012 (Brazil, 2013).

\section{Results}

Table 1 presents the sociodemographic characteristics of the study's participants.

\section{Table I - Sociodemographic characteristics of the} Brazilian immigrant women living in Portugal, 2016

\begin{tabular}{|c|c|c|}
\hline Sociodemographic characteristics & \multicolumn{2}{|c|}{ Frequency } \\
\hline Age (years) & $(\mathrm{N})$ & $(\%)$ \\
\hline $18-27$ & 106 & 15.5 \\
\hline $28-37$ & 257 & 37.7 \\
\hline $38-47$ & 183 & 26.8 \\
\hline 48-57 & 101 & 14.9 \\
\hline $58-67$ & 28 & 4.1 \\
\hline $68-76$ & 2 & 0.3 \\
\hline Did not answer & 5 & 0.7 \\
\hline Marital status & $(\mathrm{N})$ & (\%) \\
\hline Married & 325 & 47.6 \\
\hline Single & 183 & 26.8 \\
\hline Stable union & 85 & 12.5 \\
\hline Separated or divorced & 74 & 10.8 \\
\hline Widow & 13 & 1.9 \\
\hline Did not answer & 2 & 0.4 \\
\hline Education level & $(\mathrm{N})$ & $(\%)$ \\
\hline Some elementary school & 31 & 4.5 \\
\hline Elementary school & 34 & 5 \\
\hline Some high school & 52 & 7.6 \\
\hline High school & 172 & 25.2 \\
\hline Some higher education & 105 & 15.4 \\
\hline Higher education degree & 103 & 15.1 \\
\hline Postgraduate studies & 181 & 26.5 \\
\hline Did not answer & 4 & 0.7 \\
\hline Living with & $(\mathrm{N})$ & (\%) \\
\hline Their own family & 468 & 68.6 \\
\hline Alone & 99 & 14.5 \\
\hline Portuguese family & 65 & 9.5 \\
\hline Brazilian friends & 42 & 6.1 \\
\hline Did not answer & 8 & 1.3 \\
\hline Children & $(\mathrm{N})$ & $(\%)$ \\
\hline Have child(ren) & 395 & 57.9 \\
\hline Do not have child(ren) & 281 & 41.2 \\
\hline Did not answer & 6 & 0.9 \\
\hline
\end{tabular}


Table 2 presents the places of origin of the study's participants. The Southeast region stands out in this migration process and the North region has the lowest numbers.

Table 2-Distribution of the regions and states of origin of Brazilian immigrant women living in Portugal, 2016

\begin{tabular}{|c|c|c|}
\hline Region & State & Number \\
\hline \multirow{7}{*}{ North } & Pará & 20 \\
\hline & Rondônia & 13 \\
\hline & Acre & 2 \\
\hline & Amazonas & 8 \\
\hline & Roraima & 3 \\
\hline & Tocantins & 4 \\
\hline & Amapá & 1 \\
\hline Total & & 51 \\
\hline \multirow{9}{*}{ Northeast } & Alagoas & 3 \\
\hline & Bahia & 38 \\
\hline & Ceará & 35 \\
\hline & Paraíba & 27 \\
\hline & Maranhão & 10 \\
\hline & Pernambuco & 27 \\
\hline & Piauí & 5 \\
\hline & $\begin{array}{l}\text { Rio Grande do } \\
\text { Norte }\end{array}$ & 10 \\
\hline & Sergipe & 5 \\
\hline Total & & 160 \\
\hline \multirow{4}{*}{ Midwest } & Goiás & 38 \\
\hline & Mato Grosso & 48 \\
\hline & Mato Grosso do Sul & 4 \\
\hline & Federal District & 10 \\
\hline Total & & 100 \\
\hline \multirow{4}{*}{ Southeast } & Espírito Santo & 27 \\
\hline & Minas Gerais & 55 \\
\hline & São Paulo & 117 \\
\hline & Rio de Janeiro & 94 \\
\hline Total & & 293 \\
\hline \multirow{3}{*}{ South } & Paraná & 46 \\
\hline & Rio Grande do Sul & 22 \\
\hline & Santa Catarina & 10 \\
\hline Total & & 78 \\
\hline Grand total & & 682 \\
\hline
\end{tabular}

Graph 1 illustrates the districts of residence of the Brazilian immigrant women in Portugal. It is worth highlighting a piece of information: the identification and approach for in person data collection at the Consulate General of Brazil occurred for four months in the city of Porto and over 15 days in Lisbon, which may have influenced the total number of participants achieved.

\section{Graph I - Distribution of Brazilian immigrant women living in Portugal by district of residence, 2016}

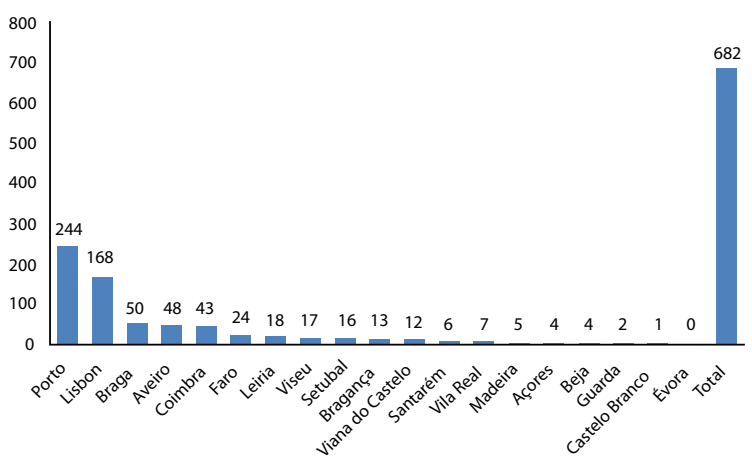

Table 3 presents the dimensions of SF- 36 and their relation with the work situation of Brazilian immigrant women living in Portugal. The unemployed showed statistically significant results on the dimensions functional capacity, emotional aspects, mental health, and health change over time.

The proof value is less than $5 \%$ for dimensions “1. Functional capacity", "7. Emotional aspects”, "8. Mental health", and "9. Health change over time". Statistically significant differences are among the classes of work situation.

In the sample, the scale of the SF-36 questionnaire offers superior value to "employed" and inferior for "unemployed" and "domestic worker/housewife". The remaining dimensions present the variations observed. However, these differences are not statistically significant.

The information in Table 4 are related to the dimensions of the SF-36 and weekly working hours. Statistically significant values were not found for all dimensions. 
Table 3 - Work situation and quality of life, taking as parameter the SF-36, of Brazilian immigrant women in Portugal, 2016

\begin{tabular}{|c|c|c|c|c|c|c|}
\hline & & $\mathrm{N}$ & Mean & Standard deviation & $\mathrm{F}$ & $p$ \\
\hline \multirow[t]{5}{*}{$\mathrm{SF}-36$} & Unemployed & 132 & 68.1 & 19,0 & 1.957 & 0.099 \\
\hline & Employed & 271 & 72.8 & 16,4 & & \\
\hline & Student & 106 & 70.5 & 17,6 & & \\
\hline & Student and worker & 29 & 72.0 & 13.8 & & \\
\hline & Domestic worker/housewife & 76 & 69.0 & 17.1 & & \\
\hline \multirow[t]{5}{*}{ I. Functional capacity } & Unemployed & 142 & 81.7 & 19.4 & 5.970 & ${ }^{* *} 0.000$ \\
\hline & Employed & 294 & 83.5 & 19.0 & & \\
\hline & Student & III & 88.4 & 12.8 & & \\
\hline & Student and worker & 30 & 93.0 & 8.2 & & \\
\hline & Domestic worker/housewife & 85 & 78.4 & 22.8 & & \\
\hline \multirow[t]{5}{*}{ 2. Physical aspects } & Unemployed & 143 & 75.9 & 36.6 & 1.715 & 0.145 \\
\hline & Employed & 293 & 83.7 & 29.9 & & \\
\hline & Student & 114 & 78.7 & 32.6 & & \\
\hline & Student and worker & 30 & 85.0 & 25.1 & & \\
\hline & Domestic worker/housewife & 83 & 79.5 & 32.9 & & \\
\hline \multirow[t]{5}{*}{ 3. Pain } & Unemployed & 143 & 72.5 & 24.0 & 0.848 & 0.495 \\
\hline & Employed & 296 & 72.7 & 24.3 & & \\
\hline & Student & 114 & 75.7 & 21.1 & & \\
\hline & Student and worker & 29 & 78.2 & 18.9 & & \\
\hline & Domestic worker/housewife & 83 & 71.4 & 24.1 & & \\
\hline \multirow[t]{5}{*}{ 4. General health conditions } & Unemployed & 138 & 69.9 & 21.6 & 1.857 & 0.116 \\
\hline & Employed & 291 & 72.9 & 20.5 & & \\
\hline & Student & 113 & 70.5 & 22.0 & & \\
\hline & Student and worker & 30 & 73.3 & 17.9 & & \\
\hline & Domestic worker/housewife & 86 & 66.4 & 21.1 & & \\
\hline \multirow[t]{5}{*}{ 5. Vitality } & Unemployed & 144 & 57.3 & 23.5 & 2.084 & 0.081 \\
\hline & Employed & 296 & 62.6 & 21.2 & & \\
\hline & Student & 112 & 59.5 & 24.8 & & \\
\hline & Student and worker & 30 & $54 \cdot 3$ & 23.8 & & \\
\hline & Domestic worker/housewife & 86 & 62.5 & 23.3 & & \\
\hline \multirow[t]{5}{*}{ 6. Social aspects } & Unemployed & 144 & 71.3 & 28.0 & 1.292 & 0.272 \\
\hline & Employed & 294 & 76.7 & 24.2 & & \\
\hline & Student & 114 & 72.8 & 26.8 & & \\
\hline & Student and worker & 30 & 71.3 & 25.7 & & \\
\hline & Domestic worker/housewife & 86 & 74.0 & 27.8 & & \\
\hline
\end{tabular}


Table 3 - Continuation

\begin{tabular}{|c|c|c|c|c|c|c|}
\hline & & $\mathrm{N}$ & Mean & Standard deviation & $\mathrm{F}$ & $p$ \\
\hline \multirow[t]{5}{*}{ 7. Emotional aspects } & Unemployed & 143 & 63.2 & 42.4 & 6.577 & ${ }^{* *} 0.000$ \\
\hline & Employed & 291 & 76.4 & 36.5 & & \\
\hline & Student & 114 & 60.5 & 41.5 & & \\
\hline & Student and worker & 30 & 48.9 & 44.4 & & \\
\hline & Domestic worker/housewife & 85 & 69.4 & 39.9 & & \\
\hline \multirow[t]{5}{*}{ 8. Mental health } & Unemployed & 143 & 61.7 & $23 \cdot 3$ & 2.939 & ${ }^{* *} 0.020$ \\
\hline & Employed & 292 & 68.7 & 20.3 & & \\
\hline & Student & 110 & 64.1 & 24.0 & & \\
\hline & Student and worker & 30 & 65.1 & 18.2 & & \\
\hline & Domestic worker/housewife & 84 & 67.5 & 20.8 & & \\
\hline \multirow[t]{5}{*}{$\begin{array}{l}\text { 9. Health change over } \\
\text { time }\end{array}$} & Unemployed & 143 & 53.7 & 23.9 & 2.657 & ${ }^{* *} 0.032$ \\
\hline & Employed & 298 & 55.9 & 22.0 & & \\
\hline & Student & 114 & 58.8 & 23.7 & & \\
\hline & Student and worker & 30 & 65.8 & 21.3 & & \\
\hline & Domestic worker/housewife & 86 & 52.9 & 20.4 & & \\
\hline
\end{tabular}

${ }^{*}$ Significant difference for $p<0.05$.

${ }^{*}$ Significant difference for $p<0.01$.

Table 4 - Weekly working hours and quality of life, taking as parameter the SF-36, of Brazilian immigrant women in Portugal, 2016

\begin{tabular}{|c|c|c|c|c|c|c|}
\hline & & $\mathrm{N}$ & Mean & Standard deviation & $\mathrm{F}$ & $p$ \\
\hline \multirow[t]{4}{*}{$S F-36$} & Less than 20 hours & 19 & 71.6 & 15.6 & 1.645 & 0.179 \\
\hline & 20 to 39 hours & 42 & 77.1 & 14.2 & & \\
\hline & 40 hours & 172 & 72.7 & 15.9 & & \\
\hline & More than 40 hours & 66 & 70.0 & 17.9 & & \\
\hline \multirow[t]{4}{*}{ I. Functional capacity } & Less than 20 hours & 20 & 86.8 & 16.4 & 0.778 & 0.507 \\
\hline & 20 to 39 hours & 45 & 87.8 & $17 \cdot 7$ & & \\
\hline & 40 hours & 187 & 84.0 & $17 \cdot 7$ & & \\
\hline & More than 40 hours & 70 & 83.0 & 21.0 & & \\
\hline \multirow[t]{4}{*}{ 2. Physical aspects } & Less than 20 hours & 21 & 82.1 & 28.7 & 0.076 & 0.973 \\
\hline & 20 to 39 hours & 44 & 84.1 & 28.6 & & \\
\hline & 40 hours & 186 & 83.3 & 30.6 & & \\
\hline & More than 40 hours & 70 & 85.0 & 28.0 & & \\
\hline \multirow[t]{4}{*}{ 3. Pain } & Less than 20 hours & 22 & 73.2 & 22.4 & 0.134 & 0.940 \\
\hline & 20 to 39 hours & 46 & 74.9 & 23.8 & & \\
\hline & 40 hours & 185 & 73.5 & 24.0 & & \\
\hline & More than 40 hours & 70 & 72.1 & 23.9 & & \\
\hline
\end{tabular}


Table 4 - Continuation

\begin{tabular}{|c|c|c|c|c|c|c|}
\hline & & $\mathrm{N}$ & Mean & Standard deviation & $\mathrm{F}$ & $p$ \\
\hline \multirow{4}{*}{$\begin{array}{l}\text { 4. General health } \\
\text { conditions }\end{array}$} & Less than 20 hours & 22 & 70.2 & 21.6 & 1.603 & 0.189 \\
\hline & 20 to 39 hours & 46 & 78.7 & 18.6 & & \\
\hline & 40 hours & 184 & 72.6 & 20.5 & & \\
\hline & More than 40 hours & 68 & 71.0 & 20.3 & & \\
\hline \multirow[t]{4}{*}{ 5. Vitality } & Less than 20 hours & 22 & $54 \cdot 3$ & 19.3 & 2.1111 & 0.099 \\
\hline & 20 to 39 hours & 46 & 65.7 & 20.1 & & \\
\hline & 40 hours & 187 & 63.0 & 21.4 & & \\
\hline & More than 40 hours & 69 & 58.6 & 23.1 & & \\
\hline \multirow[t]{4}{*}{ 6. Social aspects } & Less than 20 hours & 22 & 74.4 & 25.1 & 0.471 & 0.702 \\
\hline & 20 to 39 hours & 46 & 78.8 & 24.8 & & \\
\hline & 40 hours & 186 & 76.7 & 23.8 & & \\
\hline & More than 40 hours & 68 & 73.7 & 25.7 & & \\
\hline \multirow[t]{4}{*}{ 7. Emotional aspects } & Less than 20 hours & 21 & 69.8 & 39.3 & 0.357 & 0.784 \\
\hline & 20 to 39 hours & 43 & 72.1 & 41.1 & & \\
\hline & 40 hours & 186 & 73.5 & 38.0 & & \\
\hline & More than 40 hours & 69 & 77.8 & 36.0 & & \\
\hline \multirow[t]{4}{*}{ 8. Mental health } & Less than 20 hours & 21 & 66.1 & 19.5 & 0.827 & 0.480 \\
\hline & 20 to 39 hours & 45 & 71.9 & 19.1 & & \\
\hline & 40 hours & 185 & 68.6 & 19.8 & & \\
\hline & More than 40 hours & 69 & 66.2 & 21.9 & & \\
\hline \multirow[t]{4}{*}{ 9. Health change over time } & Less than 20 hours & 22 & 54.5 & 21.3 & 2.457 & 0.063 \\
\hline & 20 to 39 hours & 46 & 60.9 & 22.8 & & \\
\hline & 40 hours & 188 & 58.2 & 22.4 & & \\
\hline & More than 40 hours & 70 & 51.1 & 20.6 & & \\
\hline
\end{tabular}

The proof value is higher than $5 \%$ for the SF- 36 questionnaire in all dimensions; no statistically significant differences were among the classes of "weekly working hours". In the sample, the scale of the SF-36 offers superior value for who works 20 to 39 hours and lower value for those who work more than 40 hours; in addition, the dimensions presented the observed variations. However, these differences are not statistically significant.

\section{Discussion}

The age group of highest proportion is 18 to 38 years old, which accounts for $60.5 \%$ of the sample, suggesting that most participants in the study are young adults. Dutra (2013) had already reported this finding to demonstrate the prevalence of migrant women in the age group between 20 and 40 years old $(59.8 \%)$, in line with the data obtained in this research.

Regarding marital status, when grouping married women and those in stable unions, they represent $61 \%$ of the sample. Góis et al. (2009) report that $47 \%$ of women were married or in a stable union, thus reinforcing this trend. As to the nationality of the husbands, most women had Portuguese spouses. It is known that international migration influence in various ways the framework of family relationships the number of mixed marriages between Portuguese 
and Brazilians suggests a growing trend. In the case of Portugal, the situation of immigrants is quite distinct in this regard in particular, especially because of the ethnic and linguistic identity. It is observed that between 1990 and 2000 , there was a significant and continuous growth in the number of marriages between Portuguese men and Brazilian women (Bógus, 2007).

As for the schooling, postgraduate level was declared in greater proportion. These results resemble those presented in the report Mulher migrante: agente de resistência e transformação [Migrant woman: agent of resistance and transformation], about Brazilian women in the United States, regarding education declared, in which $19.6 \%$ had complete higher education. In addition, these values arose: some higher education (12.1\%), some elementary school (8.4\%), elementary school (5.6\%), some high school (15.9\%), and high school (16.8\%). Women without formal education corresponded to $1.9 \%$, and those with undeclared education level totaled $19.6 \%$. Similarities can be noticed in the proportions of both studies concerning the postgraduate level, pointing out that most Brazilian women who migrated to Portugal and to the United States have this education level (CSEM, 2014).

As for children, few offspring seems to be the best option for these women in immigrant status; most is observed to have only one child. In the study by Gonçalves (2015), the number of children was as follows: $60 \%$ did not have any, $24 \%$ had one child, $10 \%$ had two children, $4 \%$ had three children, and $2 \%$ had more than three children. The housing condition shows that most is aggregated and living with their own family. Gonçalves (2015) also found that: $61 \%$ live with family, $15 \%$ with friends, $12 \%$ alone, and $12 \%$ with boyfriend/girlfriend.

Concerning work and labor actions, it can be verified that most women develop some type of activity, which does not mean they are inserted in the formal labor market. Dutra (2013) reports the following results: $79 \%$ of women declared to be working, although only $29 \%$ were in regular situation of documentation in the country of destination, and $21 \%$ were unemployed due to lack of the documentation that allowed their insertion in the formal labor market. Currently, considering the aspect of labor and of migration policies, a new characterization of the participation of women in migration flows can be perceived from the perspective of the labor market and the circulation of the workforce at the global level (CSEM, 2015).

The insertion of immigrants in the labor market is a complex phenomenon. In the current context, the economic recession has made the job market even more competitive for new immigrants, which gives rise to pressures for the approval of antiimmigration legislation - as seen currently in the United States - which, in its turn, lead to increased illegal immigration (Ragsdale, 2013).

So far, the discussion presented a profile of the Brazilian women living in Portugal and who have contributed to the research. An important contribution to this discussion was given by Milesi \& Marinucci (2016) about the typification of women who migrate. For the authors, the number of women with an individual migratory project is increasingly growing, travelling for business reasons, often in situation of being the major providers of their home. This reflects the emancipation achieved by them in recent decades or their aspirations to this emancipation. Thus, this type of migration may constitute an empowerment instrument.

In the research, the trend of the places of choice to live appears unchanged. In the data of the National Statistics Institute (INE), the Lisbon region accounted for more than half of the Brazilian community residing in Portugal (56.7\%), followed by the regions of Center (13.9\%), North (13.4\%), Algarve (8.9\%), and Alentejo (5.6\%) (INE, 2013). In the autonomous regions of Açores and Madeira, the percentage of Brazilian residents is less than $1 \%$. The districts that concentrate more Brazilian women are Lisbon, Setúbal, Porto, Faro, and Braga (População..., 2018).

As for the states of origin in Brazil, the Southeast region remains the one that sent more Brazilians to other countries. According to the Ministry of Foreign Affairs (MRE), the proportion of Brazilian emigrants by region is as follows: Southeast $=49 \%$, South $=17.2 \%$, Northeast $=15 \%$, Midwest $=12 \%$, and North $=6.9 \%$ (Brasil, 2011). States that stand out are São Paulo, Minas Gerais, Paraná, Goiás, Rio de Janeiro, and Bahia (Brasil, 2011). 
Regarding the two hypotheses raised a priori in the design phase of the research, we confirmed the first, since the data suggested that the Brazilian immigrant women living without jobs/unemployed in Portugal present low quality of life, having as parameter the questionnaire SF-36. Thus, the functional capacity, the emotional aspects, mental health, and health change over time (dimensions of the SF-36) showed statistical significance, confirming that hypothesis.

Corroborating this, some authors relate unemployment to mental suffering and illness, which causes low self-esteem, low states of mood and humor, stress, anxiety, feelings of shame and humiliation, sleep disorders, degradation of individual selfesteem, deterioration of social relations, social prejudice and discrimination, disruption of social and affective ties, restriction of rights, economic insecurity, feelings of loneliness and failure, development of mental disorders, and increased consumption or addiction to drugs (Barros; Oliveira, 2009; Pinheiro; Monteiro, 2007; Vieira et al., 2016).

The second hypothesis, in its turn, was refuted, because the Brazilian immigrant women living in Portugal and who work more than 40 hours a week did not present significant results that indicated low quality of life, taking as parameter the SF-36. Thus, the aspects covered in the SF- 36 were not statistically significant regarding the large weekly workload - which constitutes a fundamental finding of this study.

\section{Conclusion}

This article aimed to study the migration process, work, and quality of life of Brazilian immigrant women in Portugal. We outlined two initial hypotheses, of which only the first was confirmed by the data obtained, showing the influence of unemployment in low levels of quality of life of immigrant women.

We consider important that further discussions on the migration context are conducted, concerning the relationship between unemployment and mental health consequences, especially regarding the deleterious effects that this situation can produce on the health of individuals and of the collectivities.
Given the above, the results from this research point to the need for more comprehensive studies that may subsidize public international policies and strategies to face the intrinsic problem regarding migration, gender, and work. We suggest that other studies examine in more depth the relationship between the unemployment of immigrants and the emergence of physical and mental disorders.

As a limitation of this study we can point out the fact it did not include a qualitative deepening, in which the context of work situations and quality of life could constitute a counterpoint, enriching the presented diagnosis.

We believe the creation of public policies that provide actions directed at strengthening citizen and collective awareness of immigrant women is essential to combat the various forms of discrimination in the labor market in the country they chose to live.

\section{References}

BARRETO, L. M. S.; COUTINHO, M. P. L.; RIBEIRO, C. G. Qualidade de vida no contexto migratório: um estudo com imigrantes africanos residentes em João Pessoa-PB, Brasil. Mudanças: Psicologia da Saúde, São Bernardo do Campo, v. 17, n. 2, p. 116-122, 2009.

BARROS, C. A.; OLIVEIRA, T. L. Saúde mental de trabalhadores desempregados. Psicologia: Organizações \& Trabalho, Brasília, DF, v. 9, n. 1, p. 86-107, 2009.

BÓGUS, L. M. M. Esperança além-mar: Portugal no "arquipélago migratório" brasileiro. In:

MALHEIROS, J. M. (Org.). Imigração brasileira em Portugal. Lisboa: Acidi, 2007. v. 1. p. 39-58. (Coleção Comunidade).

BRASIL. Ministério das Relações Exteriores. Censo IBGE estima brasileiros no exterior em cerca de 500 mil. Brasileiros no Mundo, Brasília, DF, 22 dez. 2011. Disponível em: <https://bit. ly/2s3Gd7g>. Acesso em: 10 jan. 2016.

BRASIL. Ministério da Saúde. Conselho Nacional de Saúde. Resolução CNS nº 466, de 12 de dezembro de 2012. Estabelece diretrizes e normas regulamentadoras de pesquisas envolvendo seres 
humanos. Diário Oficial da União, Brasília, DF, 13 jun. 2013. Disponível em: <https://bit.ly/2oZpTyq>. Acesso em: 2 jan. 2019.

COLOMBO, M. A vulnerabilidade do migrante trabalhador como instrumento para o tráfico de pessoas e o trabalho escravo. In: PRADO, E. J. P.; COELHO, R. (Org.). Migrações e trabalho. Brasília, DF: Ministério Público do Trabalho, 2015. p. 89-93.

CSEM - CENTRO SCALABRINIANO DE ESTUDOS MIGRATÓRIOS. Mulher migrante: agente de resistência e transformação. Brasília, DF, 2014. v. 5. (Série Caminhos).

CSEM - CENTRO SCALABRINIANO DE ESTUDOS MIGRATÓRIOS. Dignidade humana e mulheres migrantes. Resenha Migrações na Atualidade, Brasília, v. 26, n. 101, p. 5-6, 2015.

DE VELLIS, R. F. Scale development: theory and applications. London: Sage, 1991.

DUTRA, D. Mulheres, migrantes, trabalhadoras: a segregação no mercado de trabalho. REMHU: Revista Interdisciplinar da Mobilidade Humana, Brasília, v. 21, n. 40, p. 177-193, 2013.

FRANKEN, I.; COUTINHO, M. P. L.; RAMOS, N. Migração e qualidade de vida: um estudo psicossocial com brasileiros migrantes. Estudos de Psicologia, Campinas, v. 26, n. 4, p. 419-427, 2009.

GÓIS, P. et al. Segunda ou terceira vaga? As características da imigração brasileira recente em Portugal. Migrações, Lisboa, v. 5, p. 111-133, 2009.

GONÇALVES, V. Educação e sociedade: a realidade da educação/formação na vida da imigração brasileira em Portugal. Migrações, Lisboa, v. 12, p. 113-136, 2015 .

INE - INSTITUTO NACIONAL DE ESTATÍSTICA. Comunidade brasileira é a maior comunidade estrangeira em Portugal. Destaques, Lisboa, 19 abr. 2013. Disponível em: <https://bit.ly/2SzPcsC>. Acesso em: 25 nov. 2016.

MARÔCO, J. Análise estatística com o SPSS Statistics. 5. ed. Lisboa: Report Number, 2011. MILESI, R.; MARINUCCI, R. Mulheres migrantes e refugiadas a serviço do desenvolvimento humano dos outros. Instituto Migrações e Direitos Humanos, Brasília, DF, 8 nov. 2016. Disponível em: <https://bit.ly/2s5jkjV>. Acesso em: 27 nov. 2016.

MINAYO, M. C. S.; HARTZ, Z. M. A.; BUSS, P. M. Qualidade de vida e saúde: um debate necessário. Ciência \& Saúde Coletiva, Rio de Janeiro, v. 5, n. 1, p. 7-18, 2000.

PINHEIRO, L. R. S.; MONTEIRO, J. K. Refletindo sobre desemprego e agravos à saúde mental. Cadernos de Psicologia Social do Trabalho, São Paulo, v. 10, n. 2, p. 35-45, 2007.

POPULAÇÃO estrangeira residente em Portugal. Serviço de Estrangeiros e Fronteiras, Lisboa, 26 out. 2018 . Disponível em: <https://bit. ly/2LKugMW>. Acesso em: 10 jan. 2017.

PRADO, E. J. P.; COELHO, R. (Org.). Migrações e trabalho. Brasília, DF: Ministério Público do Trabalho, 2015.

RAGSDALE, S. Immigrants in the United States of America. Advances in Historical Studies, Madrid, v. 2, n. 3, p. 167-174, 2013.

SILVA, T. F. Precariedade laboral, raça e gênero: imigrantes brasileiras e o mercado de trabalho português. Revista de Psicologia, Fortaleza, v. 4, n. 2, p. 87-102, 2013.

TEIXEIRA, A. F.; DIAS, S. F. Labor market integration, immigration experience, and psychological distress in a multi-ethnic sample of immigrants residing in Portugal. Ethnicity and Health, Abingdon, v. 23, n. 1, p. 1-16, 2016.

VIEIRA, C. E. C. et al. Impactos psicossociais do desemprego sobre a saúde mental e subjetividade de trabalhadores de Arcos/MG. Percurso Acadêmico, Belo Horizonte, v. 6, n. 11, p. 292-295, 2016.

\section{Authors' contribution}

Oliveira designed the study, collected and analyzed the data. Matias, Félix, Cavalcante, and Lopes contributed to the analysis and discussion of the results and refinement of the article. Neto guaranteed the statistical support and carried out the final review of the material.

Received on: 09/06/2018.

Approved on: 10/22/2018. 